\title{
Investigation of $\mathbf{N}$-aryl-3-alkylidenepyrrolinones as potential Niemann-Pick type C disease therapeutics ${ }^{1}$
}

\author{
Casey C. Cosnera, John T. Markiewicza ${ }^{\mathrm{a}}$, Pauline Bourbon ${ }^{\mathrm{a}}$, Christopher J. Mariania , Olaf \\ Wiest $^{\mathrm{a}}$, Madalina Rujoi ${ }^{\mathrm{b}}$, Anton Rosenbaum ${ }^{\mathrm{b}}$, Amy Huang ${ }^{\mathrm{b}}$, Frederick R. Maxfield ${ }^{\mathrm{b}}$, and Paul \\ Helquist ${ }^{a,}{ }^{*}$ \\ aDepartment of Chemistry and Biochemistry, University of Notre Dame, 250 Nieuwland Science \\ Hall, Notre Dame, IN, 46556, USA \\ ${ }^{b}$ Department of Biochemistry, Weill Medical College of Cornell University, 1300 York Avenue, New \\ York, NY, 10021, USA
}

\begin{abstract}
A five-step synthesis of an array of $\mathrm{N}$-aryl-3-alkylidenepyrrolinones, which are potential NiemannPick type C (NPC) disease therapeutics, is described. The synthetic route allows for the production of analogues, including photoaffinity and biotinylated derivatives. Compound 1a increased esterification by acyl-coenzyme A:cholesteryl acyltransferase in NPC1 mutant cells. It also decreased LDL uptake and increased cholesterol efflux in both NPC1-deficient and normal cells.
\end{abstract}

\section{Introduction}

Niemann-Pick type $\mathrm{C}$ disease (NPC) ${ }^{1}$ is a rare autosomal recessive lipid storage disorder with most commonly a fatal neurodegenerative course. ${ }^{2}$ The disease mainly affects children, but juvenile and adult forms of the disease are also known. Some of the clinical symptoms of this disease include liver abnormalities, learning difficulties, epilepsy, vertical gaze palsy, seizures, neonatal jaundice, and finally neurodegeneration, which is the most common cause of death. ${ }^{1 a}$ On the cellular level, the most pronounced observation is an abnormal accumulation of lipids such as cholesterol, glycosphingolipids and some phospholipids in late endosome/lysosome (LE/LY)-like storage organelles (LSOs). ${ }^{3}$

NPC disease is caused by mutations in one of two genes, $n p c 1$ (95\% of all cases) and $n p c 2 .{ }^{4}$ The $n p c l$ gene encodes the 1278-residue integral membrane NPC1 protein ${ }^{5}$, which contains 13 putative transmembrane domains. The $n p c 2$ gene encodes the soluble protein NPC2 found in endosomes and possesses a cholesterol binding site. ${ }^{6}$ It has recently been reported that while both NPC1 and NPC2 proteins bind cholesterol, NPC2 accelerates the transfer of cholesterol from NPC1 to liposomes, indicating a potential necessary function of the two proteins. ${ }^{7}$ There is currently no cure for NPC disease. While attempts have been made to develop effective treatment options, ${ }^{1 \mathrm{~d}, 8}$ there remains a significant need to discover and develop useful therapeutics to treat this disease.

\footnotetext{
${ }^{1}$ Abbreviations: ACAT, acyl-coenzyme A:cholesteryl acyltransferase; CHO cells, Chinese-hamster ovary cells; DiI, 1,1'dioctadecyl-3,3,3',3'-tetramethylindocarbocyanine perchlorate; DMAP, 4-dimethylamino pyridine; EDC, $N$-(3-dimethylaminopropyl)$N$ '-ethylcarbodiimide hydrochloride; GC, gas chromatography; LDL, low-density lipoprotein; LE/LY, late endosomes/lysosomes; LSO, LE/LY-like organelles; NPC, Niemann-Pick type C disease; $\mathrm{TMSN}_{3}$, trimethylsilyl azide. 
In 2006, the Maxfield laboratory reported an automated filipin-based high-throughput screening procedure that measures the levels of filipin-bound cholesterol in the LSOs and also overall in the cell, based on images of cells stained with filipin, a fluorescent antibiotic. ${ }^{9} \mathrm{By}$ using this new technique, the Maxfield laboratory was able to screen an initial library of 14,956 compounds and found that several of these compounds lowered the filipin fluorescence intensity in the lysosomal storage compartments of CT60 and CT43 NPC1 mutant Chinese hamster ovary $(\mathrm{CHO})$ cells. This finding indicated that the free cholesterol content of these organelles was reduced.

Of the initial set of 14,956 compounds, several pyrrolinones of general structure 1 (Figure 1) exhibited significantly above average activity and consistent dose response. In addition to this activity, some of these compounds showed only mild toxicity toward normal cells in contrast to many of the other hit compounds. The dual observation of cholesterol reduction and mild toxicity of this pyrrolinone family made them an attractive target for further investigation as potential therapeutic leads for NPC disease. As such, we sought to develop a general synthesis that would allow the efficient production of a series of analogues for assay of activity in NPC1deficient cells.

The original source of $\mathbf{1}$ for screening was a commercially obtained library for which the details of synthesis were not available and from which only very limited quantities of 1 of questionable purity could be obtained. Therefore, the initial goal of the work reported in this paper was to develop an efficient, flexible, high-throughput pathway to the desired pyrrolinones with a variety of substitution patterns with both good quantity and purity. In addition to providing a series of analogues, a synthesis of pure compounds would minimize the risk of false positives in further assays. A survey of the literature revealed that there have been previous reports of the synthesis of the core 3-alkylidene-4-pyrrolin-2-one scaffold. ${ }^{10}$ Many of these routes utilize 3 -alkylidene-furan-2-ones as starting materials. ${ }^{10 \mathrm{a}, 10 \mathrm{~d}, 11} \mathrm{We}$ found that these protocols were not amenable to our needs. Given the deficiencies in previous syntheses, we set out to establish our own synthetic pathway towards the production of $\mathbf{1}$.

\section{Chemistry}

Our general route is illustrated by the synthesis of 1a (Scheme 1). Coupling methyl $p$ aminobenzoate 2 to benzoylpropionic acid using 1-ethyl-3-(3-dimethylaminopropyl) carbodiimide hydrochloride (EDC) and catalytic 4-dimethylaminopyridine (DMAP) afforded ketoamide $\mathbf{3}$. Ketoamide $\mathbf{3}$ was cyclized to acetoxypyrrole $\mathbf{4}$ after refluxing in acetyl chloride. 12 The acetyl group was cleaved using sodium borohydride in methanol, providing an inconsequential mixture of $\mathbf{5 a}$ and $\mathbf{5 b}$ in approximately a 95:5 ratio. The use of strong hydrolyzing agents such as hydroxide in this step led to decomposition of the substrates and ring-opened products.

We next prepared 6a (Scheme 2) by diazotization of 4-bromoaniline (8a) followed by a copperpromoted reaction with furfural. ${ }^{13}$ The penultimate aldol step involved submitting the mixture of 5a and $5 \mathbf{b}$ with $6 \mathbf{a}$ to Perkin condensation conditions. The Z-olefin 7 was the only observed product as determined by NOESY NMR studies. The final deprotection step using lithium iodide in refluxing pyridine, afforded the free acid 1a. ${ }^{14}$ Using this pathway, we have produced up to $5 \mathrm{~g}$ of $1 \mathrm{a}$ in highly pure form compared to the $\mathrm{mg}$ quantities of less pure material obtained from the commercial library.

To demonstrate the flexibility of our pathway and to obtain a series of analogues for NPC assays, we applied our route to the syntheses of $\mathbf{1 b}-\mathbf{g}$ (Figure 2). To obtain these analogues, the individual components were modified. The methyl ester $\mathbf{2}$ was replaced with a benzyl ester, the starting benzoylpropionic acid was derivatized to include a chlorine, and the 5-arylfurfural 6a was replaced by aldehydes $6 \mathbf{b}$ and $\mathbf{6 c}$ as well as by $p$-nitrobenzaldehyde. 
In addition to the study of analogues, another strategy to develop improved therapeutic agents is to identify their biological targets. With this information in hand, the mechanisms of action can be probed, and a combination of experimental and computational methods can be employed to design the improved compounds. We therefore set out to obtain a derivative of $\mathbf{1 a}$ for photoaffinity labeling studies to identify its biological target. ${ }^{15}$ Of the many classes of photoaffinity labeling agents available, the azides are particularly appealing for the case of 1a in that the bromide substituent should be suitable for nucleophilic exchange to produce the azide derivative $\mathbf{1 0}$.

The synthesis of $\mathbf{1 0}$ (Scheme 3) commenced with an attempted copper-catalyzed aromatic substitution known to produce azides from the corresponding bromides. ${ }^{16} \mathrm{We}$ found that the azide was presumably produced but was quickly converted to the amine 9 before consumption of the starting material was completed. This reaction was driven fully to the amine by the use of a stoichiometric equivalent of cuprous iodide. Amine $\mathbf{9}$ was converted to azide $\mathbf{1 0}$ using Moses' mild diazo transfer reaction. ${ }^{17}$

Alternatively, we also sought to obtain a derivative for biological target identification by using a biotin label ${ }^{18}$ in the form of $\mathbf{1 1}$. The synthesis of this labeled compound began by coupling known aminoazide $12^{19}$ to 1a using EDC to produce 13 (Scheme 4). The completion of the synthesis of the labeled compound was based on using the biotin propargylamide $15 .^{20}$ This compound was prepared from the readily available biotin-NHS ester $\mathbf{1 4}$ and propargyl amine. ${ }^{21}$ With both units in hand, a copper-catalyzed cyclization ${ }^{22}$ between the azide $\mathbf{1 3}$ and terminal alkyne 15 resulted in the final biotinylated analogue 17. The use of both the biotinylated analogue $\mathbf{1 1}$ and the azide $\mathbf{1 0}$ will be the subjects of a separate investigation of cellular targets.

\section{Biological Activity}

The effects of pyrrolinones 1a-g on cholesterol levels in the LSOs in CT60 and CT43 NPC1 mutant $\mathrm{CHO}$ cells had been previously assayed using a filipin-based microscopy method. ${ }^{9}$ Of these compounds, only 1a (labeled as 1a13 in the previous publication) ${ }^{9}$ exhibited significant reduction of cholesterol accumulated in the lysosomal storage organelles. Using a filipin-based image analysis assay that quantifies cholesterol accumulation in the LSOs (see details in reference 9 for the assay called LSO compartment ratio assay) it had been shown that 1a caused an $80 \%$ decrease in fluorescence in CT43 cells and 30\% in CT60 cells, at a concentration of $10 \mu \mathrm{M} .{ }^{9}$ The analogues $\mathbf{1 b}-\mathbf{1 g}$ showed no corresponding activity. Therefore, $\mathbf{1 a}$ was selected for more thorough study.

In particular, the effects of 1a on cholesterol metabolism and transport in CT60 NPC1-defective $\mathrm{CHO}$ cells were investigated. In cells with normal sterol trafficking, cholesterol (mostly esterified) is internalized into cells via lipoproteins and delivered to LE/LY, where hydrolysis of cholesteryl esters by lysosomal acid lipase takes place. ${ }^{23}$ Free cholesterol is then exported from the LE/LY and delivered to the plasma membrane and extracellular acceptors, as well as the endoplasmic reticulum, where cholesterol is esterified by the acyl-coenzyme A:cholesterol acyltransferase (ACAT) and deposited as lipid droplets. ${ }^{24}$ Cholesterol esters formed by ACAT are then hydrolyzed by cytoplasmic neutral cholesterol ester hydrolases. While low-density lipoprotein (LDL) uptake and its delivery to LE/LY are all normal in NPC-deficient cells, the rate of cholesterol efflux from the LE/LY is severely reduced. ${ }^{25}$ As a consequence, there is an obstruction in cholesterol trafficking and hence a significant decrease in the homeostatic responses in NPC-deficient cells.

We investigated the effect of 1a on cholesterol efflux and on the uptake of LDL-derived cholesterol in NPC1-deficient cells. We also evaluated the overall levels of cholesteryl ester in the cell and the esterification promoted by ACAT in the presence of this compound. Experimental results, discussed below, are summarized in Figure 3 and Table 1. 
The effect of 1a on LDL internalization was evaluated by quantifying the fluorescence intensity of DiI per cell area, normalized to the mean value of solvent-treated samples. The impact of 1a on esterification by ACAT was estimated by quantifying the incorporation of $\left[{ }^{14} \mathrm{C}\right]$-oleic acid into esters per cellular protein content. For solvent-treated cells the mean value was (14 \pm 1 ) pmol cholesteryl- $\left[{ }^{14} \mathrm{C}\right]$ ester/ $\mu \mathrm{g}$ cell protein. ${ }^{26}$ The effect of $\mathbf{1 a}$ on overall cholesteryl ester levels in the cell was determined by GC. The mean value for solvent-treated cells was $(0.042$ $\pm 0.004) \mu$ g cholesteryl ester/ $\mu \mathrm{g}$ cell protein. ${ }^{26} *$ indicates $\mathrm{p}<0.02$.

We measured the effect of compound 1a on cholesterol efflux to extracellular acceptors in the serum (e.g., high density lipoproteins) in the following cell lines: NPC1-deficient cell line CT60, its non-NPC1 parental line 25RA, and the non-NPC1 cell line TRVb1. 25RA cells are $\mathrm{CHO}$ cells with a gain of function mutation in the sterol regulatory element-binding protein cleavage activating protein (SCAP) gene. TRVb1 cells are apparently normal CHO cells transfected with a human transferrin receptor. ${ }^{27}$ The major cholesterol efflux from the $\mathrm{CHO}$ cells would be mediated by ATP-binding cassette transporter. ${ }^{28}$ Cells were labeled with $1 \mu \mathrm{Ci} /$ $\mathrm{ml}\left[{ }^{3} \mathrm{H}\right]$-cholesterol for $24 \mathrm{~h}$ and then incubated for $18 \mathrm{~h}$ with $10 \mu \mathrm{M} \mathrm{1a}$. Efflux was expressed as the radioactivity of the supernatant relative to the sum of the radioactivity of supernatant and cell monolayer. Changes in the efflux in the presence of $\mathbf{1 a}$ were compared to solventtreated control cells. We observed (Figure 3) that compound 1a increased efflux not only in NPC1-deficient CT60 cells, but also in the 25RA and TRVb1 cells, which have normal NPC1.

We studied the direct effect of 1a on LDL endocytosis by incubating the cells for a short time (35 min) with 1a and DiI-labeled LDL. We also tested the longer term effect of 1a on LDL uptake by incubating the cells for 18 hours with 1a and DiI-LDL. We observed that both in NPC1-deficient CT60 cells as well as the NPC wild type 25RA parental cells 1a causes a significant inhibition of LDL internalization (DiI-LDL uptake) during long $(18 \mathrm{~h})$ treatments. However, no significant changes in DiI-LDL uptake during short (35 min) incubations were observed, indicating that there is not a direct effect on LDL binding. For CT60 DMSO-treated cells long term uptake resulted in incorporation of $1347 \pm 65 \mathrm{fmol} \mathrm{DiI} / \mu \mathrm{g}$ cellular protein, for 25RA cells the incorporation was $1937 \pm 300 \mathrm{fmol} / \mu \mathrm{g}$ protein and for the short incubations the values were $188 \pm 20$ and $276 \pm 17 \mathrm{fmol} / \mu \mathrm{g}$, for CT60 and 25RA cells, respectively.

When we measured the overall cellular content of cholesteryl esters by gas chromatography (GC), we found no significant change in the overall cholesteryl ester levels (Table 1). However, when we tested the effect of 1a on cholesterol esterification by ACAT by quantifying the incorporation of $\left[{ }^{14} \mathrm{C}\right]$-oleic acid into cholesteryl- $\left[{ }^{14} \mathrm{C}\right]$-oleate, we observed an increase in ACAT esterification upon treatment of CT60 cells with $1 \mathrm{a}$ for $18 \mathrm{~h}$. For the solvent-treated CT60 cells the average experimental value corresponding to ACAT esterification is (14 \pm 1$)$ pmol cholesteryl- $\left[{ }^{14} \mathrm{C}\right]$-oleate/ $\mu \mathrm{g}$ cellular protein, ${ }^{9}$ while for $\mathbf{1 a}$-treated CT60 cells the value is about $20.9 \mathrm{pmol} / \mu \mathrm{g}$ protein. The restoration by $\mathbf{1 a}$ of the ACAT esterification in NPCdeficient CT60 cells is significant, since in the solvent-treated non-NPC mutant 25RA experimental value is $37 \pm 3$ pmol cholesteryl- $\left[{ }^{14} \mathrm{C}\right]$-oleate $/ \mu \mathrm{g}$ cellular $(\mathrm{n}=27$, six independent experiments). The fact that the overall levels of cholesteryl ester did not change upon treatment with 1a, while the ACAT esterification was increased may be related to an indirect effect of cholesterol accumulation in LSOs, which can lead to increased formation of cholesteryl esters in these organelles. ${ }^{29}$

In this paper and in our previous study, ${ }^{9}$ we described several effects of 1a on NPC1-deficient cells. There is reduced filipin labeling of unesterified cholesterol in the LSOs, ${ }^{9}$ there is an increase in efflux of cholesterol to extracellular acceptors (Figure 3), decreased uptake of LDL (Table 1), and increased cholesterol esterification by ACAT (Table 1). All of these changes would be consistent with release of cholesterol from the LSOs in response to treatment with 1a. The cholesterol released from the LSOs would be a substrate for ACAT and would be 
expected to increase incorporation of radiolabeled oleate into cholesteryl ester droplets. This released cholesterol would also be expected to increase cholesterol efflux and to down-regulate the expression of LDL receptors through the SREBP pathway. ${ }^{30}$ The lack of an increase in cellular cholesteryl esters (Table 1) may seem paradoxical since there is increased esterification by ACAT. However, it has been reported that net hydrolysis of lipoprotein-derived cholesteryl esters in lysosomes stalls when levels of unesterified cholesterol in these organelles becomes high, as would be the case in NPC1-deficient cells. ${ }^{29}$ The amounts of cholesteryl esters in the LSOs of untreated NPC1-deficient cells is not known, but loss of this cholesteryl ester pool may balance the increase in the cytoplasmic lipid droplets. We also found that total unesterified cellular cholesterol as measured by GC was increased in the cells treated with 1a, and total filipin fluorescence from the whole cell area was essentially unchanged. ${ }^{9}$ Although NPC1deficient cells have high amounts of cholesterol in the LSOs, their other membranes may actually be cholesterol-poor as compared to wild type cells. ${ }^{1}$ Thus, a treatment that releases cholesterol from the LSOs would not be expected to decrease the overall cholesterol level in the cells. The previously reported increase in cholesterol in response to $\mathbf{1 a}$ is not fully understood. It may reflect a transient condition as the cells deal with release of a large amount of cholesterol from the LSOs.

Since compound 1a increased not only the esterification by ACAT, but also cholesterol efflux to extracellular acceptors, this compound could be considered a valuable candidate for directly promoting sterol efflux from the LE/LY in NPC1-deficient and other cells.

\section{Conclusion}

In summary, we have devised a concise and efficient route for the production of the goal $\mathrm{N}$ aryl-3-alkylidenepyrrolinones comprising five simple steps. When applied to initial compound 1a, the route provided the desired product in $43 \%$ overall yield. The route has also facilitated the synthesis of analogues. Furthermore, using our primary scaffold, we were able to synthesize photoaffinity labeled and biotinylated derivatives for use in separate investigations. Studies of 1a show that it decreases the LDL uptake and increases ACAT esterification in mutant-NPC1 cells, and it increases cholesterol efflux in NPC1-mutant and normal cells.

\section{Experimental Section}

All experiments were run under inert atmosphere unless otherwise stated. Thin layer chromatography (TLC) was conducted using precoated silica gel $60 \mathrm{~F}_{254}$ plates from EMD Chemicals. Infrared spectra were recorded on a Perkin Elmer Paragon 1000 FT-IR Spectrometer. HRMS data were recorded on a JEOL JMS-AX505HA double sector mass spectrometer using FAB. NMR spectra were recorded using Varian-INOVA 500 and 300 spectrometers operating at $500 \mathrm{MHz}\left({ }^{1} \mathrm{H}\right)$ and $125 \mathrm{MHz}\left({ }^{13} \mathrm{C}\right)$ and $300 \mathrm{MHz}\left({ }^{1} \mathrm{H}\right)$ and $75 \mathrm{MHz}$ $\left({ }^{13} \mathrm{C}\right)$, respectively. Chemical shifts are given in ppm relative to residual solvent peaks: ${ }^{1} \mathrm{H}$ (7.27 for $\mathrm{CDCl}_{3}$ and 2.5 for DMSO- $d_{6}$ ) and ${ }^{13} \mathrm{C}$ (77.23 for $\mathrm{CDCl}_{3}$ and 39.51 for DMSO- $d_{6}$ ). Flash chromatography was performed using EcoChrome $60 \AA$ silica gel. All tested compounds were $>95 \%$ pure by HPLC.

\section{(Z)-4-(3-((5-(4-Bromophenyl)furan-2-yl)methylene)-2-oxo-5-phenyl-2,3-dihydro-1H-pyrrol-1- yl)benzoic acid (1a)}

Pyrrolinone 7 ( $1.15 \mathrm{~g}, 1.9 \mathrm{mmol})$ was added to freshly distilled pyridine $(8 \mathrm{~mL})$ at $23{ }^{\circ} \mathrm{C}$. To this mixture was added anhydrous lithium iodide $(3.56 \mathrm{~g}, 26.6 \mathrm{mmol})$. This mixture was heated to reflux and stirred at this temperature for $14 \mathrm{~h}$. During this time, the mixture became homogeneous and darkened in color. The reaction mixture was cooled to $23^{\circ} \mathrm{C}$ and poured into ice cold $1 \mathrm{~N} \mathrm{HCl}$. The $\mathrm{pH}$ of the solution was adjusted to 2 , and the precipitated red solid was collected by vacuum filtration. The solid cake was washed with $1 N \mathrm{HCl}(2 \times 20 \mathrm{~mL})$ and 
DI water $(2 \times 20 \mathrm{~mL})$. The solid was allowed to air dry, affording $1.12 \mathrm{~g}$ of $\mathbf{1 a}(95 \%) .{ }^{1} \mathrm{H}$ NMR matched that of an a commercial sample. $\mathrm{mp}=>200{ }^{\circ} \mathrm{C} .{ }^{1} \mathrm{H}$ NMR $\left(500 \mathrm{MHz}, \mathrm{DMSO}-d_{6}\right) \delta$ $7.92(\mathrm{~d}, J=8 \mathrm{~Hz}, 2 \mathrm{H}), 7.83(\mathrm{~d}, J=8 \mathrm{~Hz}, 2 \mathrm{H}), 7.71(\mathrm{~d}, J=8 \mathrm{~Hz}), 7.38-7.34(\mathrm{~m}, 5 \mathrm{H}), 7.32-7.29$ $(\mathrm{m}, 2 \mathrm{H}), 7.23-7.20(\mathrm{~m}, 3 \mathrm{H}), 6.84(\mathrm{~s}, 1 \mathrm{H}) ;{ }^{13} \mathrm{C}\left(125 \mathrm{MHz}, \mathrm{DMSO}-d_{6}\right) \delta$ 169.2, 167.4, 156.4, 152.7, 146.7, 140.2, 132.9, 131.0, 130.4, 129.9, 129.5, 129.3, 128.9, 128.3, 127.6, 127.2, 126.9, 125.7, 122.6, 118.1, 111.4, 111.4, 104.5; HRMS (FAB) calcd for $\mathrm{C}_{28} \mathrm{H}_{18} \mathrm{BrNO}_{4}(\mathrm{M}+\mathrm{H})^{+}$ 512.0497, found 512.0485; IR (KBr pellet): 3418, 3057, 1706, 1683, 1605, 1470, 1173, 1112 $\mathrm{cm}^{-1}$.

\section{Synthesis of azido-1a (10)}

To a flame dried flask was added $9(107 \mathrm{mg}, 0.24 \mathrm{mmol})$ and DMSO (ca $4 \mathrm{~mL})$. Neat tertbutylnitrite $(0.1 \mathrm{~mL}, 0.8 \mathrm{mmol})$ was added, followed by neat azidotrimethylsilane $(0.2 \mathrm{~mL}, 1.5$ $\mathrm{mmol}$ ) which was accompanied by the emission of a small quantity of gas. The solution was stirred for $30 \mathrm{~min}$ at $25^{\circ} \mathrm{C}$. Excess $\mathrm{TMSN}_{3}$ and ${ }^{\mathrm{t}} \mathrm{BuONO}$ were removed directly from the reaction flask with vacuum $(1 \mathrm{mmHg})$ and a dry ice trap. Deionized water $(200 \mathrm{~mL})$ was added to form a fine suspension, which was filtered through an ultrafine Teflon ${ }^{\circledR}$ membrane $(45 \mu \mathrm{m})$ to obtain 10 as a red powder $(83 \mathrm{mg}, 74 \%) . \mathrm{mp}=130-140{ }^{\circ} \mathrm{C} \mathrm{dec} ;{ }^{1} \mathrm{H} \mathrm{NMR}(600 \mathrm{MHz}$, DMSO- $\left.d_{6}\right) \delta 7.93(\mathrm{~d}, J=9 \mathrm{~Hz}, 2 \mathrm{H}), 7.92(\mathrm{~d}, J=8.4 \mathrm{~Hz}, 2 \mathrm{H}) 7.36(\mathrm{~m}, 4 \mathrm{H}), 7.32-7.30(\mathrm{~m}, 3 \mathrm{H})$ $7.27(\mathrm{~d}, J=9 \mathrm{~Hz}, 2 \mathrm{H}), 7.22(\mathrm{~d}, J=8.4 \mathrm{~Hz}) ,7.21(\mathrm{~s}, 1 \mathrm{H}), 6.85(\mathrm{~d}, J=0.6 \mathrm{~Hz}, 1 \mathrm{H}) ;{ }^{13} \mathrm{C}$ NMR (600 MHz, DMSO-d6) 169.0, 167.2, 156.7, 152.2, 146.2, 140.2, 140.0, 130.8, 130.2, 129.6, 129.2, 129.1, 128.0, 127.4, 126.5, 126.4, 125.1, 122.5, 120.5, 118.0, 110.4, 104.3; IR (KBr) 3415 (w), 3057 (w), 3031 (w), 2123 (s), 2089 (s) 1705 (s), 1686 (s), 1603 (s) 1281 (s) 1174 (m); HRMS (FAB) calcd for $\mathrm{C}_{28} \mathrm{H}_{19} \mathrm{~N}_{4} \mathrm{O}_{4}(\mathrm{M}+\mathrm{H})^{+} 475.1406$, found 475.1412.

\section{Synthesis of biotin labeled 1a (11)}

13 (47 mg, $0.066 \mathrm{mmol})$ was dissolved in acetone $(1 \mathrm{~mL})$ at $23{ }^{\circ} \mathrm{C} .15(19 \mathrm{mg}, 0.066 \mathrm{mmol})$ was added, and the mixture was stirred under nitrogen. To this stirring mixture was added cupric sulfate $(<1 \mathrm{mg}$, dissolved in $<1 \mathrm{~mL}$ of water) via syringe, followed by sodium ascorbate $(1.3 \mathrm{mg}, 6.6 \mu \mathrm{mol}$ dissolved in $<1 \mathrm{~mL}$ of water). The mixture slowly became homogeneous, and was stirred for 24 hours. The reaction was concentrated and the residue was purified by column chromatography using a gradient (100\% EtOAc to $100 \% \mathrm{MeOH})$ to yield $48 \mathrm{mg}(73 \%)$ of a bright red solid. ${ }^{1} \mathrm{H}$ NMR $\left(600 \mathrm{MHz}, \mathrm{CDCl}_{3}\right) \delta 7.78(\mathrm{~d}, J=9.0 \mathrm{~Hz}, 3 \mathrm{H}), 7.71(\mathrm{t}, J=5.4$ $\mathrm{Hz}, 1 \mathrm{H}), 7.60-7.56(\mathrm{~m}, 4 \mathrm{H}), 7.44(\mathrm{t}, J=5.4 \mathrm{~Hz}, 1 \mathrm{H}), 7.33-7.27(\mathrm{~m}, 3 \mathrm{H}), 7.22-7.20(\mathrm{~m}, 3 \mathrm{H})$, $7.12(\mathrm{~d}, J=8.4 \mathrm{~Hz}, 2 \mathrm{H}), 6.89(\mathrm{bd}, 2 \mathrm{H}), 6.83(\mathrm{~d}, J=4.2 \mathrm{~Hz}, 1 \mathrm{H}), 6.73(\mathrm{~s}, 1 \mathrm{H}), 6.24(\mathrm{bs}, 1 \mathrm{H})$, 4.51-4.46 (m, 2H), $4.41(\mathrm{t}, J=3 \mathrm{~Hz}, 2 \mathrm{H}), 4.38-4.34(\mathrm{~m}, 1 \mathrm{H}), 4.29-4.26(\mathrm{~m}, 1 \mathrm{H}), 3.77(\mathrm{t}, J=$ $4.8 \mathrm{~Hz}, 2 \mathrm{H}), 3.68-3.66(\mathrm{~m}, 2 \mathrm{H}), 3.65-3.62(\mathrm{~m}, 2 \mathrm{H}), 3.60-3.58(\mathrm{~m}, 2 \mathrm{H}), 3.57-3.56(\mathrm{~m}, 2 \mathrm{H})$, $3.55-3.53(\mathrm{~m}, 2 \mathrm{H}), 3.09-3.06(\mathrm{~m}, 1 \mathrm{H}), 2.86(\mathrm{dd}, J=12.6 \mathrm{~Hz}, 4.8 \mathrm{~Hz}, 1 \mathrm{H}), 2.71(\mathrm{~d}, J=12.6 \mathrm{~Hz}$, $1 \mathrm{H}), 2.20-2.12(\mathrm{~m}, 2 \mathrm{H}), 1.63-1.57(\mathrm{~m}, 4 \mathrm{H}), 1.42-1.32(\mathrm{~m}, 2 \mathrm{H}) ;{ }^{13} \mathrm{C} \mathrm{NMR}(150 \mathrm{MHz}, \mathrm{CDCl} 3)$ $\delta 173.6,169.7,167.2,164.6,156.5,152.8,146.4,145.0,138.6,132.8,12.4,131.0,129.3,128.8$, $128.7,127.9,127.8,126.8,126.1,126.0,123.8,122.8,120.9,118.1,109.5,104.5,70.6,70.59$, $70.55,70.3,69.87,69.5,61.9,60.4,55.8,50.3,40.8,40.0,35.9,24.6$; HRMS (ESI) (M + H) 995.254 ; IR (film): 3300, 3000, 2928,2864, 1757, 1699, 1649, 1504, 1354, $758 \mathrm{~cm}^{-1}$.

\section{Supplementary Material}

Refer to Web version on PubMed Central for supplementary material.

\section{Acknowledgments}

The authors thank the Ara Parseghian Medical Research Foundation and the University of Notre Dame for financial support of this research. This work was also supported by NIH grant R37-DK27083 to FRM. Also, we thank Prof. J. David Warren and Dr. Guangtao Zhang of the Milstein Organic Synthesis Core Facility of Cornell University for their 
help with DiI chromatography and B. Attawut for help in preparing DiI-LDL. MR was supported by a grant from the WM Keck Foundation.

\section{References}

1. For recent reviews, see: a) Sturley SL, Patterson MC, Balch W, Liscum L. The pathophysiology and mechanisms of NP-C disease. Biochim. Biophys. Acta 2004;1685:83-87. [PubMed: 15465429] b) Mukherjee S, Maxfield FR. Lipid and cholesterol trafficking in NPC. Biochim. Biophys. Acta 2004;1685:28-37. [PubMed: 15465424] c) Maxfield FR, Tabas I. Role of cholesterol and lipid organization in disease. Nature 2005;438:612-621. [PubMed: 16319881] d) Wraith, JE.; Imrie, J. Malden: Blackwell Publishing Co; 2007. Understanding Niemann-Pick Disease Type C and Its Potential Treatment; p. 1-36.

2. Cataldo, AM.; Nixon, RA. Neuronal Protein Trafficking in Alzheimer's Disease and Niemann-Pick Type C Disease. In: Bean, AJ., editor. Protein Trafficking in Neurons. New York, NY: Academic Publishing; 2007. p. 391-411.

3. Liscum L, Ruggiero RM, Faust JR. The intracellular-transport of low-density lipoprotein derived cholesterol is defective in Niemann-Pick type C fibroblasts. J. Cell Biol 1989;108:1625-1636. [PubMed: 2715172]

4. Walkley SU, Suzuki K. Consequences of NPC1 and NPC2 loss of function in mammalian neurons. Biochim. Biophys. Acta -Molecular and Cell Biology of Lipids 2004;1685:48-62.

5. Infante RE, Abi-Mosleh L, Radhakrishnan A, Dale JD, Brown MS, Goldstein JL. Purified NPC1 Protein: I. Binding of Cholesterol and Oxysterols to a 1278-Amio Acid Membrane Protein. J. Biol Chem 2008;283:1052-1063. [PubMed: 17989073]

6. Xu S, Benoff B, Liou HL, Lobel P, Stock AM. Structural basis of sterol binding by NPC2, a lysosomal protein deficient in Niemann-Pick type C2 disease. J. Biol Chem 2007;282:23525-23531. [PubMed: 17573352]

7. Infante RE, Wang ML, Radhakrishnan A, Kwon HJ, Brown MS, Goldstein JL. NPC2 facilitates bidirectional transfer of cholesterol between NPC1 and lipid bilayers, a step in cholesterol egress from lysosomes. Proc. Natl. Acad. Sci. U.S.A 2008;105:15287-15292. [PubMed: 18772377]

8. a) Liscum L, Arnio E, Anthony M, Howley A, Sturley SL, Agler M. Identification of a pharmaceutical compound that partially corrects the Niemann-Pick C phenotype in cultured cells. J. Lipid Res 2002;43:1708-1717. [PubMed: 12364555] b) Patterson MC, Platt F. Therapy of Niemann-Pick disease, type C. Biochim. Biophys. Acta 2004;1685:77-82. [PubMed: 15465428] c) Helquist P, Wiest O. Current status of drug therapy development for Niemann-Pick type $\mathrm{C}$ disease. Drugs Fut 2009;34:315-331.

9. Pipalia NH, Huang A, Ralph H, Rujoi M, Maxfield FR. Automated microscopy screening for compounds that partially revert cholesterol accumulation in Niemann-Pick C cells. J. Lipid Res 2006;47:284-301. [PubMed: 16288097]

10. a) Egorova AY, Sedavkina VA, Timofeeva ZY. Synthesis and structure of 5-alkyl(aryl)pyrrol-2-ones. Chem. Heterocycl. Comp 2001;37:550-553. b) Egorova AY. Synthesis of arylidene derivatives of N-unsubstituted pyrrolin-2-ones. Russ. Chem. Bull., Int. Ed 2002;51:183-184. c) Egorova AY, Nesterova VV. Synthesis of arylidene derivatives of 1-aryl-3H-pyrrol-2-ones. Chem. Heterocycl. Comp 2004;40:1002-1006.

11. Filler R, Piasek EJ, Leipold HA. $\alpha$-Benzylidene- $\gamma$-phenyl- $\Delta \beta, \gamma$-butenolide. Org. Synth 1963;43:3-5.

12. Tsolomiti G, Tsolomitis A. An unxpected simple synthesis of N-substituted 2-acetoxy-5-arylpyrroles and their hydrolysis to 3 and 4-pyrrolin-2-ones. Tetrahedron Lett 2004;45:9353-9355.

13. Holla BS, Malini KV, Sarojini BK, Poojary B. A novel three-component synthesis of triazinothiazolones. Synth. Commun 2005;35:333-340.

14. (a) Elsinger F, Schreiber J, Eschenmoser A. Notiz über die Selektivität der Spaltung von Carbonsäuremethylestern mit Lithiumjodid. Helv. Chim. Acta 1960;43:113-118. (b) Fisher JW, Trinkle KL. Iodide dealkylation of benzyl, PMB, PNB, and t-Butyl N-acyl amino acid esters via lithium ion coordination. Tetrahedron Lett 1994;35:2505-2508.

15. Fleming SA. Chemical Regents in Photoaffinity Labeling. Tetrahedron 1995;51:12479-12520.

16. Andersen J, Madsen U, Bjorkling F, Liang XF. Rapid synthesis of aryl azides from aryl halides under mild conditions. Synlett 2005:2209-2213. 
17. Barral K, Moorhouse AD, Moses JE. Efficient Conversion of Aromatic Amines into Azides: A OnePot Synthesis of Triazole Linkages. Org. Lett 2007;9:1809-1811. [PubMed: 17391043]

18. Marks KM, Nolan GP. Chemical labeling strategies for cell biology. Nat. Methods 2006;3:591-596. [PubMed: 16862131]

19. Schwabacher AW, Lane JW, Schiesher MW, Leigh KM, Johnson CW. Desymmetrization Reactions: Efficient Preparation of Unsymmetrically Substituted Linker Molecules. J. Org. Chem 1998;63:1727-1729.

20. Zhao XZ, Semenova EA, Liao C, Nicklaus M, Pommier Y, Burke TR. Biotinylated biphenyl ketonecontaining 2,4-dioxobutanoic acids designed as HIV-1 integrase photoaffinity ligands. Bioorg. Med. Chem 2006;14:7816-7825. [PubMed: 16908168]

21. Susumu K, Uyeda HT, Medintz IT, Pons T, Delehanty JB, Matoussi H. Enhancing the Stability and Biological Functionalities of Quantum Dots via Compact Multifunctional Ligands. J. Am. Chem. Soc 2007;129:13987-13996. [PubMed: 17956097]

22. Rostovtsev VV, Green LG, Fokin VV, Sharpless KB. A Stepwise Huisgen Cycloaddition Process: Copper(I)-catalyzed Regioselective "Ligation" of Azides and Terminal Alkynes. Angew. Chem. Int. Ed 2002;41:2596-2599.

23. a) Goldstein JL, Dana SE, Faust JR, Beaudet AL, Brown MS. Role of lysosomal acid lipase in the metabolism of plasma low density lipoprotein. Observations in cultured fibroblasts from a patient with cholesteryl ester storage disease. J. Biol. Chem 1975;250:8487-8495. [PubMed: 172501] b) Goldstein JL, Basu SK, Brown MS. Receptor-mediated endocytosis of low-density lipoprotein in cultured cells. Methods Enzymol 1983;98:241-260. [PubMed: 6321901]

24. Chang TY, Chang CC, Cheng D. Acyl-coenzyme A: cholesterol acyltransferase. Annu. Rev. Biochem 1997;66:613-638. [PubMed: 9242919]

25. Sokol J, Blanchette-Mackie J, Kruth HS, Dwyer NK, Amende LM, Butler JD, Robinson E, Patel S, Brady RO, Comly ME, Vanier MT, Pentchev PG. Type C Niemann-Pick disease. Lysosomal accumulation and defective intracellular mobilization of low density lipoprotein cholesterol. J. Biol. Chem 1988;263:3411-3417. [PubMed: 3277970]

26. Rosenbaum AI, Rujoi M, Huang AY, Du H, Grabowski GA, Maxfield FR. Biochem. Biophys. Acta, Mol. Cell Biol. Lipids. 2009in press

27. McGraw TE, Greenfield L, Maxfield FR. Functional expression of the human transferring receptor CDNA in Chinese-hamster ovary cells deficient in endogenous transferring receptor. J. Cell Biol 1987;105:207-214. [PubMed: 3611186]

28. Sun Y, Hao M, Luo Y, Liang C, Silver DL, Cheng C, Maxfield FR, Tall AR. Stearoyl CoA desaturase inhibits ATP-binding cassette transporter A1-mediated cholesterol and efflux modulates membrane domain structure. J Biol. Chem 2003;278:5813-5820. [PubMed: 12482877]

29. Wang Y, Castoreno AB, Stockinger W, Nohturfft A. Modulation of endosomal cholesteryl ester metabolism by membrane cholesterol. J. Biol. Chem 2005;280:11876-11886. [PubMed: 15657032]

30. Brown MS, Goldstein JL. The SREBP pathway: Regulation of cholesterol metabolism by proteolysis of a membrane-bound transcription factor. Cell 1997;89:331-340. [PubMed: 9150132] 


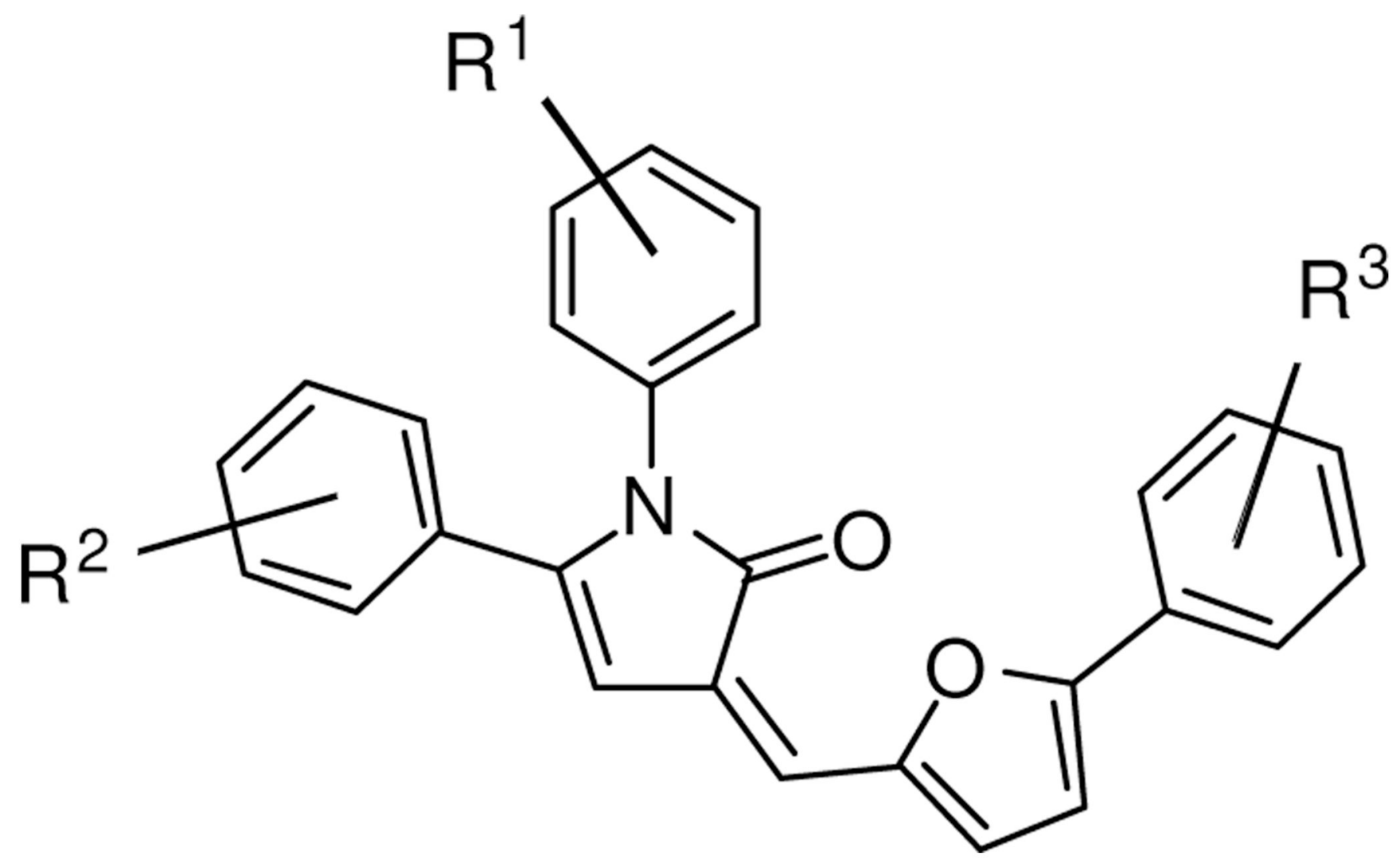

Figure 1.

Pyrrolinones of general structure 1. 
<smiles>COC(=O)c1ccc(N2C(=O)/C(=C\c3ccc(-c4ccc(Cl)c(Cl)c4)o3)C=C2c2ccccc2)cc1</smiles><smiles>COC(=O)c1ccc(N2C(=O)/C(=C\c3ccc(-c4ccc(C(F)(F)F)cc4)o3)C=C2c2ccccc2)cc1</smiles>

$1 e$<smiles>O=C(O)c1ccc(N2C(=O)/C(=C\c3ccc(-c4ccc(Cl)c(Cl)c4)o3)C=C2c2ccccc2)cc1</smiles><smiles>O=C(O)c1ccc(N2C(=O)/C(=C\c3ccc(-c4ccc(C(F)(F)F)cc4)o3)C=C2c2ccccc2)cc1</smiles>

$1 f$<smiles>O=C(OCc1ccccc1)c1ccc(N2C(=O)/C(=C\c3ccc(-c4ccc(Br)cc4)o3)C=C2c2ccc(Cl)cc2)cc1</smiles>

1d<smiles>O=C1/C(=C\c2ccc([N+](=O)[O-])cc2)C=C(c2ccc(Cl)cc2)N1c1cccc(I)c1</smiles>

$1 \mathrm{~g}$

Figure 2.

The library of pyrrolinone analogues produced by the general scheme. 


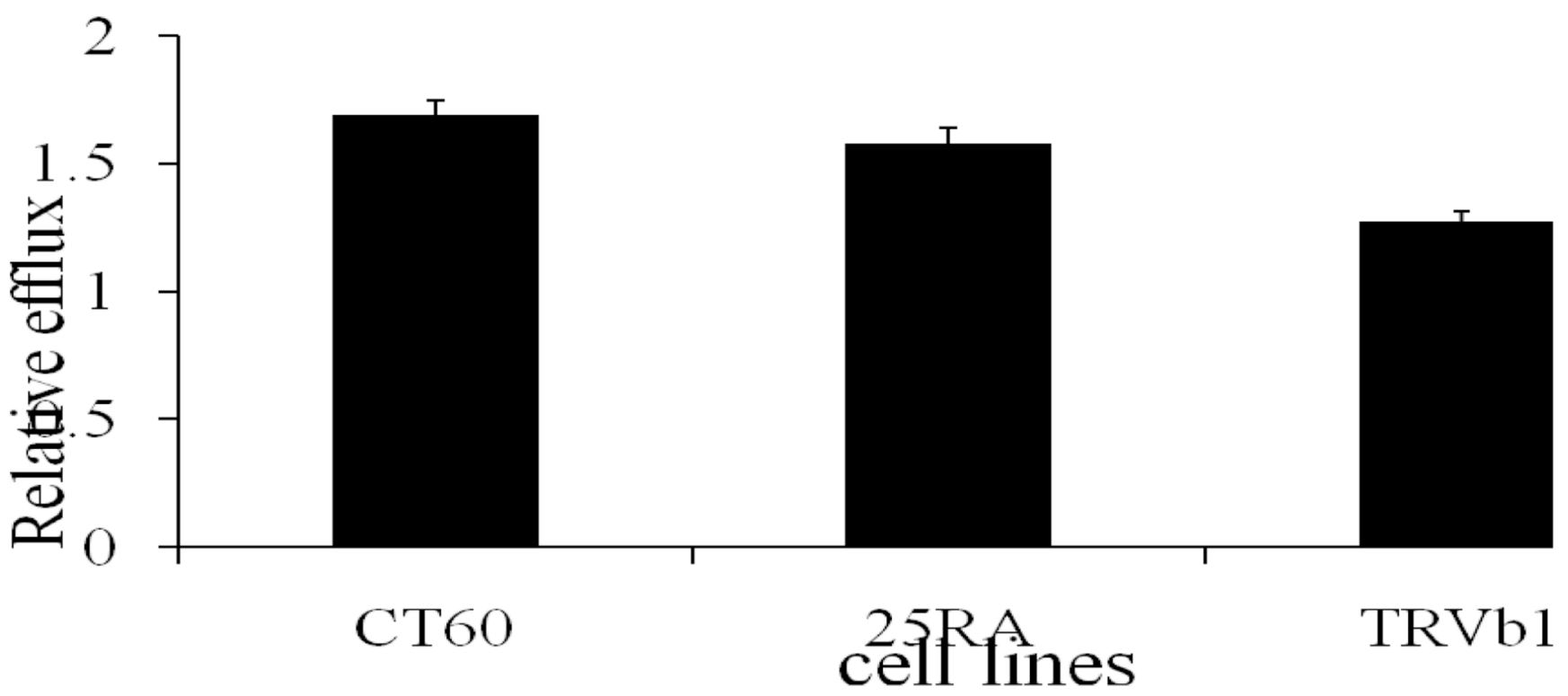

Figure 3.

Relative increase in cholesterol efflux by $1 \mathbf{a}$ in normal (TRVb1, 25RA) and mutant (CT60) $\mathrm{CHO}$ cells. Cells were labeled with $1 \mu \mathrm{Ci} / \mathrm{ml}\left[{ }^{3} \mathrm{H}\right]$-cholesterol for $24 \mathrm{~h}$ and then incubated for $18 \mathrm{~h}$ with $10 \mu \mathrm{M}$ 1a. Efflux was expressed as the radioactivity of the supernatant relative to the total of the radioactivity in the supernatant and the cell monolayer. For solvent-treated (control) cells, the mean values of supernatant/total were: $0.069 \pm 0.003$ for CT60 cells, 0.066 \pm 0.004 for 25RA cells and $0.214 \pm 0.006$ for TRVb1 cells. Experimental data of 1a-treated cells are presented as relative efflux with respect to the control $(\mathrm{p}<0.001)$. Five independent experiments $(n=25)$ were run in CT60 cells, and 2 independent experiments $(n=10)$ for 25RA and TRVb1 cells. 
<smiles>CC(=O)c1ccc(NC(=O)CCC(=O)c2ccccc2)cc1</smiles><smiles>COc1ccc(-c2ccccc2)n1-c1ccc(C(C)=O)cc1</smiles>

4<smiles>CC(=O)c1ccc(N2C(=O)CC=C2c2ccccc2)cc1</smiles>

$5 b$<smiles>CC(C)C=O</smiles><smiles>CC(=O)c1ccc(N2C(=O)/C(=C/c3ccc(-c4ccc(Br)cc4)o3)C=C2c2ccccc2)cc1</smiles><smiles>O=C(O)c1ccc(N2C(=O)/C(=C\c3ccc(-c4ccc(Br)cc4)o3)C=C2c2ccccc2)cc1</smiles>

$1 \mathrm{a}$

Scheme 1.

Reagents and conditions: a) 3-benzoylpropionic acid, EDC, DMAP, $\mathrm{CH}_{2} \mathrm{Cl}_{2}, 0^{\circ} \mathrm{C}, 80 \%$ b) $\mathrm{AcCl}$, DMAP, reflux, $90 \%$ c) $\mathrm{NaBH}_{4}, \mathrm{MeOH}, 0{ }^{\circ} \mathrm{C}, 85 \%$ d) $6 \mathbf{a}, \mathrm{NaOAc}, \mathrm{Ac}_{2} \mathrm{O}, 100{ }^{\circ} \mathrm{C}, 75 \%$ e) LiI, pyridine, reflux, $95 \%$. 


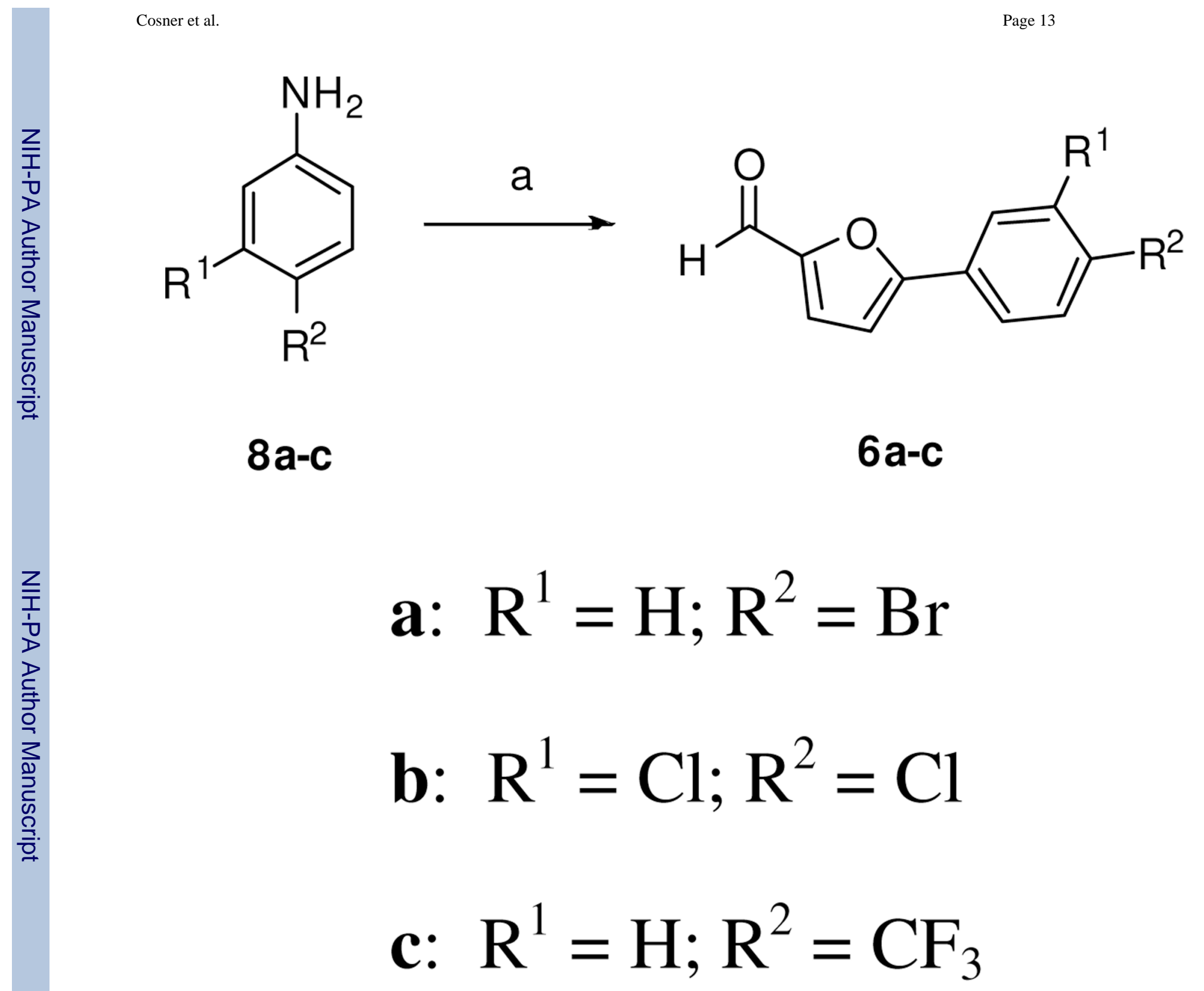

Scheme 2.

Reagents and conditions: a) i. $\mathrm{NaNO}_{2}, \mathrm{HCl}$ ii. 2-furaldehyde, $\mathrm{CuCl}_{2}$, acetone. 
<smiles>Nc1ccc(-c2ccc(/C=C3/C=C(c4ccccc4)N(c4ccc(C(=O)O)cc4)C3=O)o2)cc1</smiles>

Scheme 3.

Reagents and conditions: a) $\mathrm{Na}_{2} \mathrm{CO}_{3}, \mathrm{NaN}_{3}, \mathrm{CuI}, \mathrm{N}, \mathrm{N}^{\prime}$-dimethylethylenediamine, DMSO, $85 \%$ b) $t \mathrm{BuONO}, \mathrm{TMSN}_{3}$, DMSO, $74 \%$ 


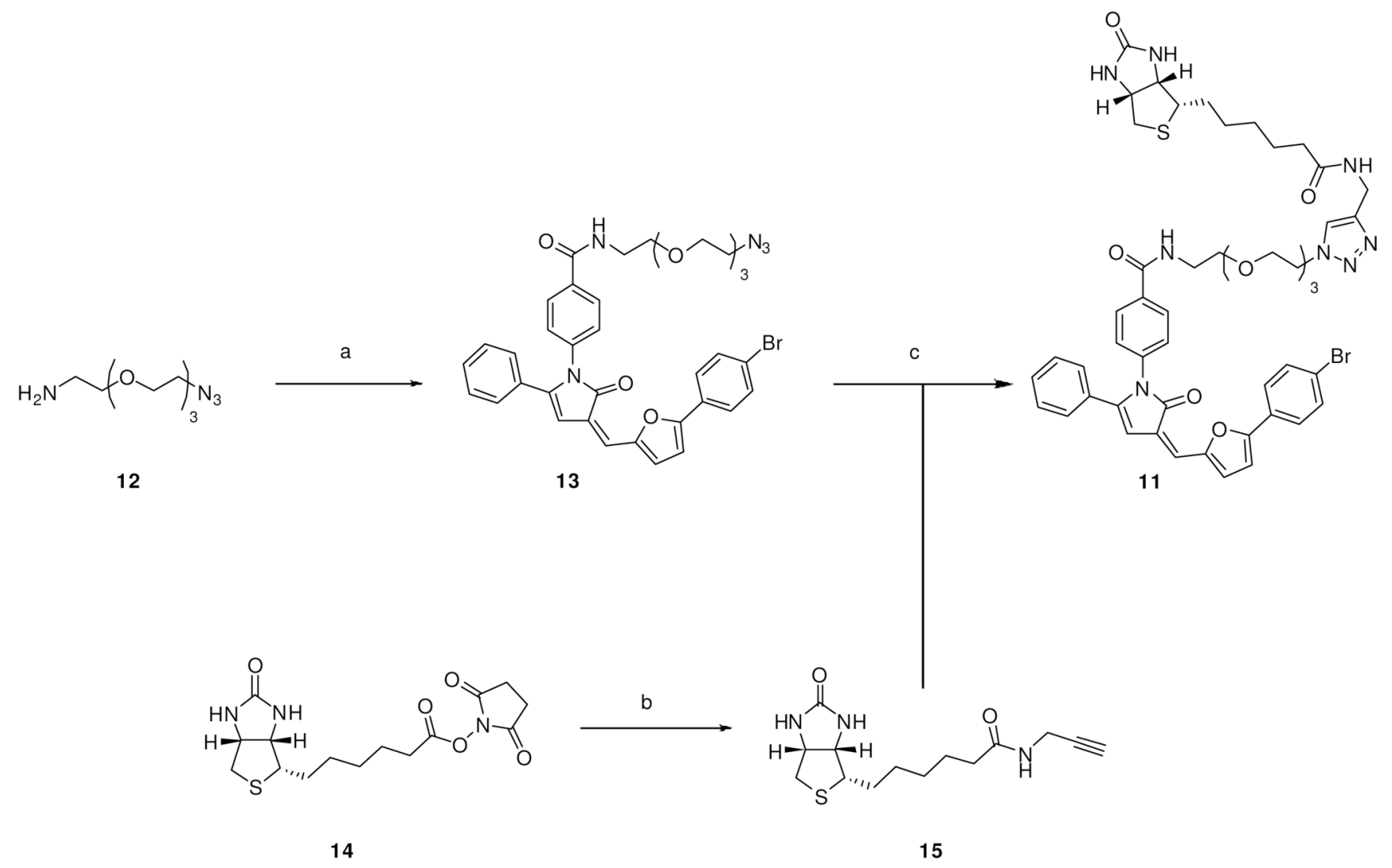

Scheme 4.

Reagents and conditions: a) 1a, EDC, DMAP, pyridine, $65 \%$ b) propargylamine, DMF, $92 \%$ c) $\mathbf{1 5}, \mathrm{CuSO}_{4}$, sodium ascorbate, acetone, $73 \%$ 


\section{Table 1}

Summary of the effects of $10 \mu \mathrm{M} 1 \mathrm{a}$ in NPC1-deficient CT60 cells.

\begin{tabular}{|l|l|}
\hline Assay & $\begin{array}{l}\text { Average value } \pm \text { S.E. } \\
\text { fraction of the control }\end{array}$ \\
\hline Endocytosis of DiI-LDL in CT60 cells: 35 min uptake & $0.93 \pm 0.05$ \\
\hline Endocytosis of DiI-LDL in 25RA cells: 35 min uptake & $1.16 \pm 0.31$ \\
\hline Endocytosis of DiI-LDL in CT60 cells: $18 \mathrm{~h}$ uptake of DiI-LDL & $0.59 \pm 0.06^{*}$ \\
\hline Endocytosis of DiI-LDL in 25RA cells: $18 \mathrm{~h}$ uptake of DiI-LDL & $0.67 \pm 0.03^{*}$ \\
\hline ACAT esterification: Incorporation of [ ${ }^{14} \mathrm{C}$-oleic acid into esters & $1.49 \pm 0.13^{*}$ \\
\hline Cholesteryl esters levels evaluated by GC & $1.05 \pm 0.10$ \\
\hline
\end{tabular}

